\title{
Acoustic Properties for the Kazakh Velar and Uvular Distribution
}

\author{
Heather Lynn Yawney ${ }^{*}$
}

\begin{abstract}
Kazakh has an asymmetrical dorsal consonant inventory. Velars and uvulars are involved in two restrictions. First, the dorsal consonants are restricted in their place of articulation depending on neighbouring vowels. Velars appear in front vowel environments and uvulars appear in back vowel environment. Second, the dorsal consonants are restricted in voicing in the stem-final position. Voiceless velars and uvulars appear word-finally, while voiced velars and uvulars appear intervocalically with a following vowel-initial suffix. The existing descriptions regarding Kazakh dorsals contain limited amounts of data, and so an elicitation-based production experiment using nonce words with a native Kazakh speaker was conducted. Different acoustic properties, including closure duration, voice onset time, frication duration, centre of gravity, vowel duration, and F2 values, were examined with the purpose of determining whether the speaker varied in their production of target velars and uvulars that could distinguish between place of articulation and voicing. The acoustic properties reveal that the place of articulation restriction is not productive, while the voicing restriction is productive.
\end{abstract}

Keywords. Kazakh; dorsals; velars; uvulars; place of articulation; voicing; acoustic properties

1. Introduction. Many Turkic languages have consonant inventories that include velar and uvular (dorsal) consonants. ${ }^{1}$ While the specific consonant inventories can vary within this language family, many exhibit place of articulation and voicing restrictions. Little descriptive work is available on these restrictions in Turkic languages and so my research aims to bridge the gap in the literature by looking at Kazakh velars and uvulars and focusing on the morpheme boundary.

This paper is organised as follows. Section 2 presents background information about what is known about Kazakh velars and uvulars. Section 3 presents the guiding research questions and a short description of the elicitations with one native Kazakh speaker. Section 4 presents the acoustic results from the speaker's recordings. Section 5 presents some main discussion points that arose from the results. Section 6 briefly concludes.

2. Background. This section provides details of what is already known about velars and uvulars in Kazakh. First, the number of velar and uvular consonants is asymmetrical (\$2.1). Second, the place restriction exhibits velar and uvular alternants depending on neighbouring vowels (\$2.2). Native Kazakh words show velars appearing in front vowel environments and uvulars appearing in back vowel environments (Muhamedowa 2016). Third, the voicing restriction depends on the position of the stem-final velars and uvulars within a word (\$2.3). Word-final velars and uvulars are voiceless and stem-final intervocalic velars and uvulars are voiced with a following vowelinitial suffix (Kara 2002). Fourth, loanwords, including words containing /x/, are exceptions to vowel harmony and can remain nonharmonic (\$2.4) (Bekturova \& Bekturov 1996). Nothing is

\footnotetext{
I w would like to thank my supervisor, Dr. Peter Jurgec, for his ongoing support and feedback, all individuals for their clarification questions or suggestions during different presentations of my research, two anonymous reviewers for their helpful feedback, and my speaker for sharing their language with me. Heather Lynn Yawney, University of Toronto (heather.yawney@mail.toronto.ca).

${ }^{1}$ See Johanson and Johanson (1998). This book offers overviews of different Turkic languages written by different authors.
} 
known about what happens to the voiceless fricative $/ \mathrm{x} /$ found in loanwords and it is unclear whether $/ \mathrm{x} /$ exhibits any place of articulation or voicing restrictions.

2.1. VELAR AND UVULAR CONSONANT INVENTORY. The velar and uvular consonant inventory in Kazakh is asymmetrical. The number of velars and uvulars is imbalanced, as the inventory shows in (1).

(1) Kazakh velar and uvular consonants ${ }^{2}$

\begin{tabular}{|l|c|c|c|c|}
\hline & \multicolumn{2}{|c|}{ VELAR } & \multicolumn{2}{c|}{ UVULAR } \\
\hline STOPS & {$[\mathrm{k}]$} & {$[\mathrm{g}]$} & {$[\mathrm{q}]$} & \\
\hline FRICATIVES & {$[\mathrm{x}]$} & & & {$[\mathrm{b}]$} \\
\hline
\end{tabular}

There are several details to take notice of in the inventory above. First, there are no voiced alternants for the velar fricative and the uvular stop. There is also no voiceless alternant for the uvular fricative. Second, there is a disparity in the place restriction. [k] alternates with [q] while maintaining voicing and manner of articulation, but [g] alternates with [ $\mathrm{b}$ ] while maintaining voicing but not manner of articulation (see Muhamedowa 2016). Third, there is a disparity in the voicing restriction. [k] alternates with [g] in voicing while maintaining manner of articulation, but [q] alternates with [в] in voicing without maintaining manner of articulation (see Kara 2002). Fourth, the segment found in loanwords, [x], can alternate freely with [q] (e.g., [xat] [qat] 'letter' (Bekturova \& Bekturov 1996)), whereby the alternation differs in both place and manner of articulation. ${ }^{3}$

2.2. PlaCE RESTRICTION. Velars and uvulars are restricted in their place of articulation depending on adjacent vowels (Muhamedowa 2016). A key feature found in native Kazakh words is vowel harmony, whereby all vowels in a word are either front or back, and this affects whether a velar or uvular consonant appears. A word usually contains only front or back vowels, as the examples show in (2).

(2)Examples of front and back vowel harmony within a word (after Bekturova \& Bekturov 1996, Bowman \& Lokshin 2014)

\begin{tabular}{|c|c|c|c|}
\hline \multicolumn{2}{|c|}{ FRONT VOWELS } & \multicolumn{2}{|c|}{ BACK VOWELS } \\
\hline \multicolumn{2}{|c|}{ WITH VELAR CONSONANTS } & WITH UVULA & CONSONANTS \\
\hline$\left[\int \mathrm{e} m \mathrm{Ir} \int \mathrm{e} \mathbf{k}\right]$ & 'gristle' & [3omurtqa] & 'egg' \\
\hline [kyrek] & 'shovel' & [sarumsaq] & 'garlic' \\
\hline [esIk] & 'door' & [qalam] & 'pen' \\
\hline [kepemet] & 'amazing' & [qазаz] & 'paper' \\
\hline [tyngi $]$ & 'night time' & [basan] & 'column' \\
\hline [søgis] & 'pasture' & [salum] & 'scholar' \\
\hline$\left[\int \mathrm{IgIt}\right]$ & ‘young' & [balкa] & 'hammer' \\
\hline
\end{tabular}

The examples above show that words containing front vowels have velars appearing and words containing back vowels have uvulars appearing (Muhamedowa 2016).

\footnotetext{
${ }^{2}$ Voiceless sounds are on the left side of the column and voiced sounds are on the right side of the column.

${ }^{3}$ The literature is not clear in whether the voiceless fricative is velar or uvular place of articulation.
} 
Vowel harmony and the distribution of velars and uvulars also play a role in morphologically complex forms. Front or back alternants in suffixes harmonise with the stem and assimilate in voicing to the directly proceeding consonant (see Muhamedowa 2016), as the dative marker examples show in (3). ${ }^{4}$

(3) Harmony with the dative suffix $-G A$

\begin{tabular}{|c|c|c|c|}
\hline \multicolumn{4}{|c|}{ a. FRONT VOWELS } \\
\hline ROOT & & ROOT-DAT & \\
\hline [keme] & 'ship' & [keme-ge] & 'to the ship' \\
\hline [felek] & 'bucket' & [ elek-ke] & 'to the bucke \\
\hline [sæbız] & 'carrot' & [sæbiz-ge] & 'to the carrot \\
\hline \multicolumn{4}{|c|}{ b. BACK VOWELS } \\
\hline ROOT & & ROOT-DAT & \\
\hline [awa] & ‘air’' & [awa-sa] & 'to the air' \\
\hline [bas] & 'head' & [bas-qa] & 'to the head' \\
\hline [tuz] & 'salt' & [tuz-sa] & 'to the salt' \\
\hline
\end{tabular}

The examples above show that the realisation of the dative marker varies depending onto which stem it attaches. With regard to the vowel, if the stem vowel is front, the suffix vowel is front [e], and if the stem vowel is back, the suffix vowel is back [a]. With regard to the consonant, if the stem vowel is front, the suffix consonant is velar $[\mathrm{k} / \mathrm{g}]$, and if the stem vowel is back, the suffix consonant is uvular $[\mathrm{q} / \mathrm{r}]$. With regard to voicing, if the stem ends with a voiceless consonant, the suffix consonant begins with voiceless $[\mathrm{k} / \mathrm{q}]$, and if the stem ends with a voiced consonant or a vowel, the suffix consonant begins with voiced $[\mathrm{g} / \mathrm{s}]$.

2.3. VOICING RESTRICTION. Velar and uvular consonants are restricted in voicing depending on the position of stem-final consonant in a word (Kara 2002). Another key feature found in Kazakh is the voicing alternation at the morpheme boundary, whereby voiced or voiceless velars and uvulars appear depending on whether the consonant appears word-finally or intervocalically. The two phonological phenomena examined are final devoicing and stem-final intervocalic voicing with a following vowel-initial suffix, as the examples show in (4).

(4)Examples of velar alternations (after Bekturova \& Bekturov 1996)

$\begin{array}{llll} & \text { WORD-FINAL } & & \text { INTERVOCALIC } \\ \text { VELAR } & {[\text { kywælik] }} & \text { 'identity card' } & \text { [kywæligim] 'my identity card' } \\ \text { UVULAR } & \text { [qasuq] } & \text { 'spoon' } & \text { [qasuru] }\end{array}$

The examples above show word-final voiceless velars and uvulars appear and intervocalic voiced velars and uvulars appear when a vowel-initial suffix follows (Kara 2002). Voiceless and voiced pairs of velars and uvulars alternate with each other. However, it is unclear whether Kazakh has word-final devoicing or intervocalic voicing, or both. Also, nothing is known about whether the articulation of stem-final $[\mathrm{x}]$ alternates in voicing depending on its position in a word.

\footnotetext{
${ }^{4}$ The realisation of the dative suffix -GA is dependent on the frontness of the preceding vowel of the word $(\mathrm{A}=\mathrm{e}[-\mathrm{back}], \mathrm{a}[+\mathrm{back}])$ and whether the stem ends in a voiceless consonant $(\mathrm{G}=\mathrm{k}$ [-back], $\mathrm{q}[+\mathrm{back}])$, or in a voiced consonant or a vowel $(\mathrm{G}=\mathrm{g}[-\mathrm{back}]$, в [+back]).
} 
2.4. LOANWORDS.Loanwords and words containing $[\mathrm{x}]$ are exceptions to vowel harmony and can remain nonharmonic, like the examples shown in (5) (Kara 2002, Muhamedowa 2016).

(5)Loanwords in Kazakh (after Batayeva 2013, Kara 2002)

$\begin{array}{lll}{[\mathrm{kitap}]} & \text { 'book' } & \text { (Arabic) } \\ {[\mathrm{kæmzol}]} & \text { 'sort of blouse' } & \text { (Persian) } \\ {[\text { sumkæ] }} & \text { 'bag' } & \text { (Russian) } \\ {[\text { tarix }]} & \text { 'history' } & \text { (Arabic) }\end{array}$

The examples above show that loanwords can contain front and back vowels. Nothing is known about whether the place of articulation of $/ \mathrm{x} /$ alternates depending on the surrounding vowel environment. $^{5}$

3. Research questions and elicitations. This section provides brief details on the research questions and what was involved during the elicitations. The existing descriptions contain limited amounts of data. This does not allow for any concrete generalisations to be drawn about the full distribution of Kazakh velars and uvulars. Several questions remain unanswered: Are velars and uvulars contrastive intervocalically? What happens to [x]? Is the restriction on velars next to front vowels and uvulars next to back vowels productive? Does next to the vowel mean before, after, or either?

To answer my research questions, I conducted two elicitation-based production experiments with a native Kazakh speaker using orthographic nonce word stimuli to obtain data for some preliminary results. The speaker was a 26 year old female who fluently speaks Russian as her second language and English as her third language at the time of the experiment. Before moving to Toronto, Ontario, Canada three years prior, she resided in the southern region city of Almaty where she spoke Kazakh at home and her formative grade school years, as well as her undergraduate and master's degrees, were given in Kazakh. After moving to Canada, she obtained a post-secondary diploma and entered the workforce.

The first elicitation tested whether the place restriction found in real words can be extended to nonce words. This involved the speaker reading a list of $40 \mathrm{CVCV}(20 \mathrm{Cvcv}$ and $20 \mathrm{cvCv})$ and $40 \mathrm{CVCCVC}(20 \mathrm{cvCcvc}$ and $20 \mathrm{cvccvC})$ nonce words out loud, each token three times. ${ }^{6}$ The nonce words targeted velars and uvulars in different positions of the word (onset/coda, wordinitial/-medial/-final). The second elicitation tested whether the voicing restriction found in real words can be extended to nonce words. The original $20 \mathrm{cvccvC}$ nonce words were used and the task involved the speaker deriving the nonce words as if they were nouns (in plural -LAr and first person plural possessive -(I)mIz forms) and verbs (in past tense -DI, present/future with converb -A, and infinitive - $\mho \mathrm{w}$ forms). ${ }^{7}$ The data were analysed with the accompanying spectrograms using Praat (Boersma 2001).

\footnotetext{
$5 / \mathrm{x} /$ has the same grapheme in Kazakh whether it appears adjacent to a front or back vowel. Additionally, Kazakh differentiates $/ \mathrm{k} /, / \mathrm{g} /, / \mathrm{q} /$, and $/ \mathbf{\mathrm { s }} /$ with separate graphemes.

${ }^{6}$ Uppercase $\mathrm{C}$ represents the position of the target velars and uvulars.

${ }^{7}$ The different realisations of the plural suffix -LAr are -der/-dar/-ter/-tar/-ler/-lar, the different realisations of the first person plural possessive -(I)miz are -(I)miz/-(u)muz, the different realisations of the past tense -DI are -di/$\mathrm{du} /$-tI/-tu, and the different realisations of the present/future with converb -A are -e/-a. The specific form that is realised depends on the frontness of the preceding vowel of the word and whether the stem ends in a voiced or
} 
4. Acoustic results. This section provides details on the different acoustic properties examined, including closure duration $(\S 4.1)$, voice onset time ( $\$ 4.2)$, frication duration ( $\S 4.3)$, centre of gravity (\$4.4), vowel duration ( $\$ 4.5)$, and F2 transition into/out of target velars and uvulars (§4.6). The purpose of examining the different acoustic properties is to determine whether the speaker varies in the values regarding voiced and voiceless stops and fricatives.

4.1. Closure DURATION. This section presents the results for the closure duration of $/ \mathrm{k} /, / \mathrm{g} /$, and /q/. The word-initial stops were not included because of the difficulty in determining the beginning of a voiceless stop when the speaker produced the tokens in isolation. ${ }^{8}$ The variation of the stop closure duration can be an indication for the voicing feature of consonants (see Lehiste 1970, Maddieson 1997). The common pattern cross-linguistically reveals shorter closure durations for voiced stops relative to voiceless stops.

The results show overall that voiced stops have shorter closure duration and voiceless stops have longer close durations based on the median values. This can be shown in Figure 1 for the target velars and uvulars in different positions of the word. ${ }^{9}$
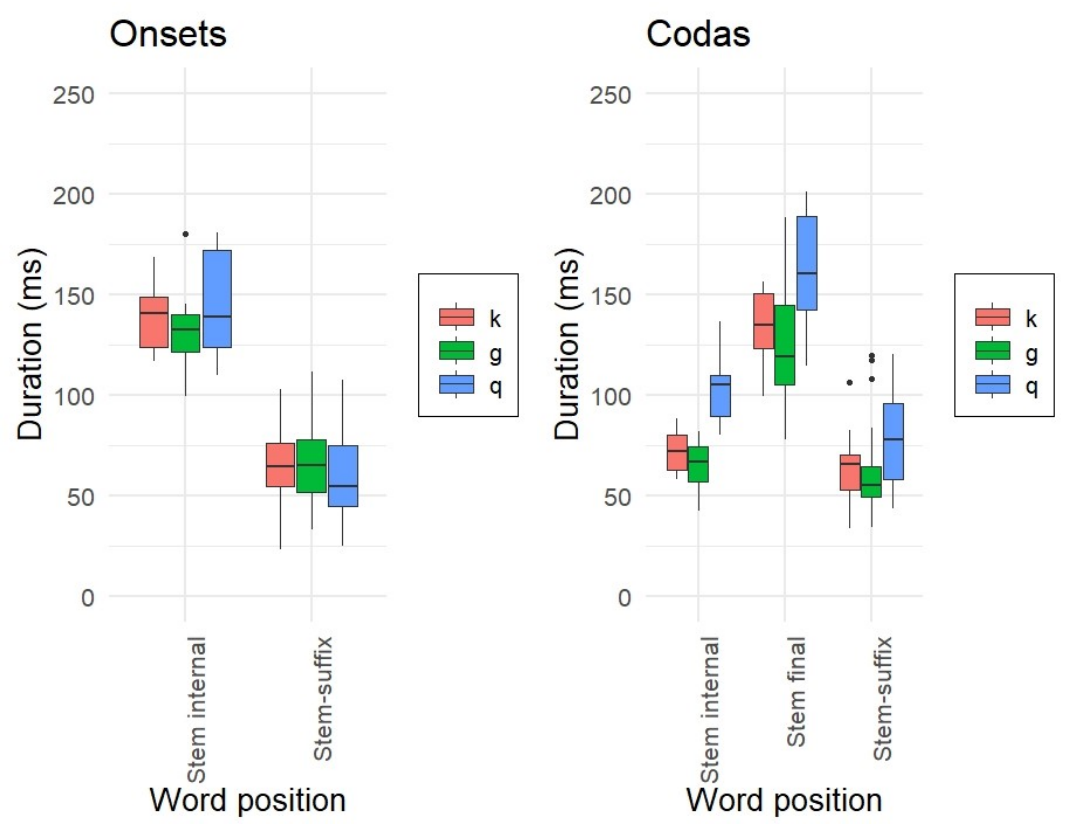

Figure 1. Stop closure durations of target velar and uvular consonants /k/,/g/, and /q/

voiceless consonant or a vowel. The infinitive does not have different realisations and is always - $\mho w$ regardless of the frontness of the preceding vowel.

${ }^{8}$ A reviewer commented about the possible difficulty to also determine the closure duration for word-final stops. In response, the speaker released their word-final stops and so I was able to code for the closure duration of word-final $/ \mathrm{k} /, / \mathrm{g} /$, and $/ \mathrm{g} /$, as well as the stop release/burst.

${ }^{9}$ The following labels in each figure have the following meaning: Under Onsets, Stem initial refers to Cvcv nonce words, Stem internal refers to cvCv nonce words, and Stem-suffix refers to cvecvC-suffix nonce words where the suffix begins with a vowel and the stem-final consonant has been resyllabified into onset position, and, under Codas, Stem internal refers to cvCcvc nonce words, Stem final refers to cvecvC nonce words and Stem-suffix refers to cvecvC-suffix nonce words where the suffix begins with a consonant and the stem-final consonant remains in coda position. The vowel-initial suffixes include first person plural possessive -(I)mIz forms, present/future with converb -A forms, and infinitive - $\mho w$ forms, and the consonant-initial suffixes include plural -Lar and past tense -DI. 
The figure shows some exceptions to the generalisation. First of all, stem-internal values seem to follow the overall pattern whereby voiced stops have shorter closure duration values than voiceless stops. Second, the stem boundary shows some neutralisation effects, which is not surprising based on what we know about the voicing patterns. Stem-final coda voiced target consonants show longer closure duration values word-finally. This differs with stem-final target voiceless consonants that show shorter closure durations at the stem-suffix boundary in onset position with a following vowel-initial suffix. Third, closure durations at the stem-suffix boundary in coda position with a following consonant-initial suffix don't show much of a difference when compared to stem-internal codas. These results are indications of word-final devoicing and intervocalic voicing with a following vowel-initial suffix but no voicing effects with a following consonant-initial suffix.

4.2. VOICE ONSET TIME. This section presents the results for the voice onset time of $/ \mathrm{k} /, / \mathrm{g} /$, and /q/. Differing from the previous section that addresses the closure duration, the word-initial stops are included because you can measure the duration of the burst to the beginning of voicing. However, like the stop closure duration, voice onset time can also be an indication for voiced stops relative to voiceless stops (Cho and Ladefoged 1999). The common pattern reveals shorter voice onset time for voiced stops relative to voiceless stops. Furthermore, the closure of more posterior stops should have longer voiced onset time relative to the closure of more anterior stops.

The results show overall that voiced stops have shorter voice onset times and voiceless stops have longer voice onset time based on the median values. This can be shown in Figure 2.
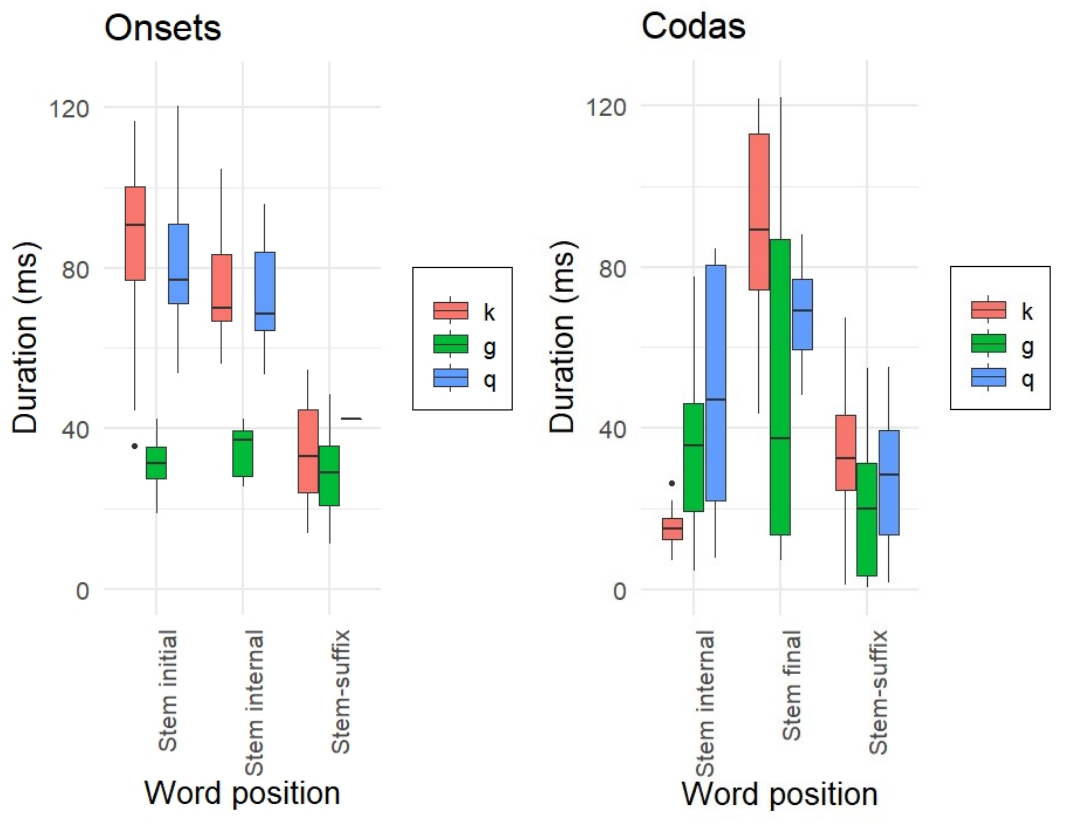

Figure 2. Voice onset time of target dorsal consonants $/ \mathrm{k} /, / \mathrm{g} /$, and $/ \mathrm{q} /$

The target stem-initial consonants clearly follow the generalisation across the board. However, the above figure shows some exceptions to the generalisations. First, stem-internal onsets follow the overall pattern whereby voiced stops have shorter voice onset time values than voiceless stops, but stem-internal codas deviate. Additionally, target stem-internal $/ \mathrm{k} /$ show shorter values 
relative to $/ \mathrm{g} /$, although $/ \mathrm{q} /$ respects the generalisation for longer voice onset time values for voiceless stops. Second, the stem boundary shows some neutralisation effects. Similar to what we saw in the previous section, this is unsurprising based on what we know about the voicing patterns. Stem-final target voiceless consonants show shorter voice onset time at the stem-suffix boundary in onset position with a following vowel-initial suffix. However, it is unclear how stem-final dorsals pattern based on the range of values and the similar values relative to other positions in the word. Third, the voice onset time values at the stem-suffix boundary in coda position with a following consonant-initial suffix show a similar pattern to the closure durations when compared to stem-internal codas. Fourth, it is unsurprising that there is only one value for /q/ in onset position at the stem-suffix boundary because stem-final /q/ in Kazakh alternates with the voices uvular fricative $/ \mathrm{s} /$ intervocalically when followed by a vowel-initial consonant. Thus, no stem-final /q/ would surface in the intervocalic position. These results are indications of word-final devoicing and intervocalic voicing with a following vowel-initial suffix but no voicing effects with a following consonant-initial suffix.

4.3. FRICATION DURATION. This section presents the results for the frication duration of $/ \mathrm{x} /$ and $/ \mathrm{s} /$. The variation of the frication duration can be an indication for the voicing feature of consonants (see Klatt 1976, Akpanglo-Narty 1982). Manrique and Massone (1981) examined the duration of frication noise in Spanish voiced and voiceless fricatives and found "little or no overlap between duration ranges" (p. 1147) between the mean durations of voiced and voiceless fricatives. The expected pattern is shorter frication duration for voiced fricatives relative to voiceless fricatives.

The results show overall that voiced fricatives have shorter frication durations and voiceless fricatives have longer frication durations based on the median values. This can be shown in Figure 3.
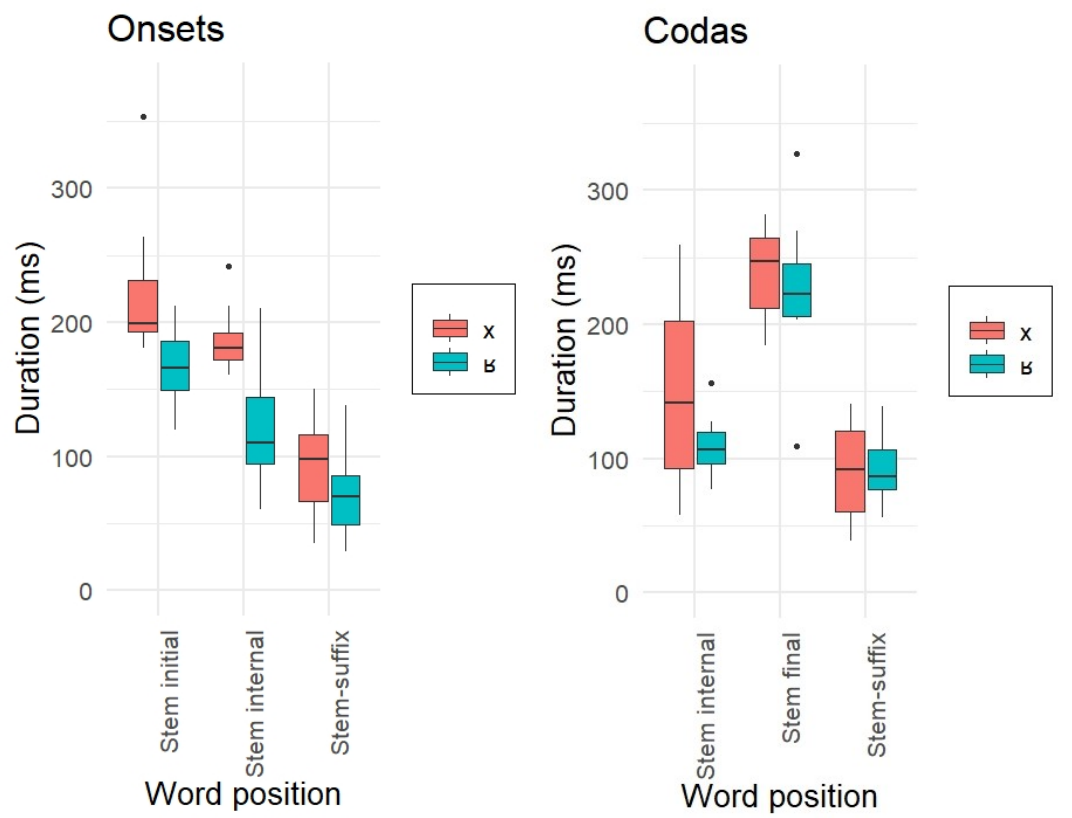

Figure 3. Frication duration of target dorsal consonants $/ \mathrm{x} /$ and $/ \mathrm{b} /$ 
The target stem-initial and stem-internal consonants clearly follow the generalisation across the board whereby voiced fricatives have shorter frication durants than voiceless fricatives. However, the stem boundary shows some neutralisation effects, which is not surprising based on what we know about the voicing patterns. Stem-final coda voiced target consonants show longer frication duration values word-finally. This differs with stem-final target voiceless consonants that show shorter closure durations at the stem-suffix boundary in onset position with a following vowel-initial suffix. Frication durations at the stem-sufix boundary in coda position with a following consonant-initial suffix don't show much of a difference when compared to steminternal codas. These results are indications of word-final devoicing and intervocalic voicing with a following vowel-initial suffix but no voicing effects with a following consonant-initial suffix.

4.4. Centre of Gravity. This section presents the results for the centre of gravity of $/ \mathrm{x} /$ and $/ \mathrm{b} /$ in all positions of the word. The centre of gravity can be an indication for differentiating the place of articulation feature of many fricatives. Location in pronunciation of a fricative affects the centre of gravity values (Gordon et al. 2002). As well, higher centre of gravity values are expected for voiceless fricatives, with their lack of low frequency energy, relative to voiced fricatives, with this low frequency energy (Gradoville 2011). Finally, higher centre of gravity values are expected for velars than for uvulars. More anterior articulations generally have their primary spectral peaks at higher energy frequencies than for more posterior articulations with lower energy frequencies (Gordon et al. 2002).

The results show overall that voiceless fricatives have higher centre of gravity values than voiced fricatives, and velars have higher centre of gravity values than uvulars, based on the median values. This can be shown in Figure 4.

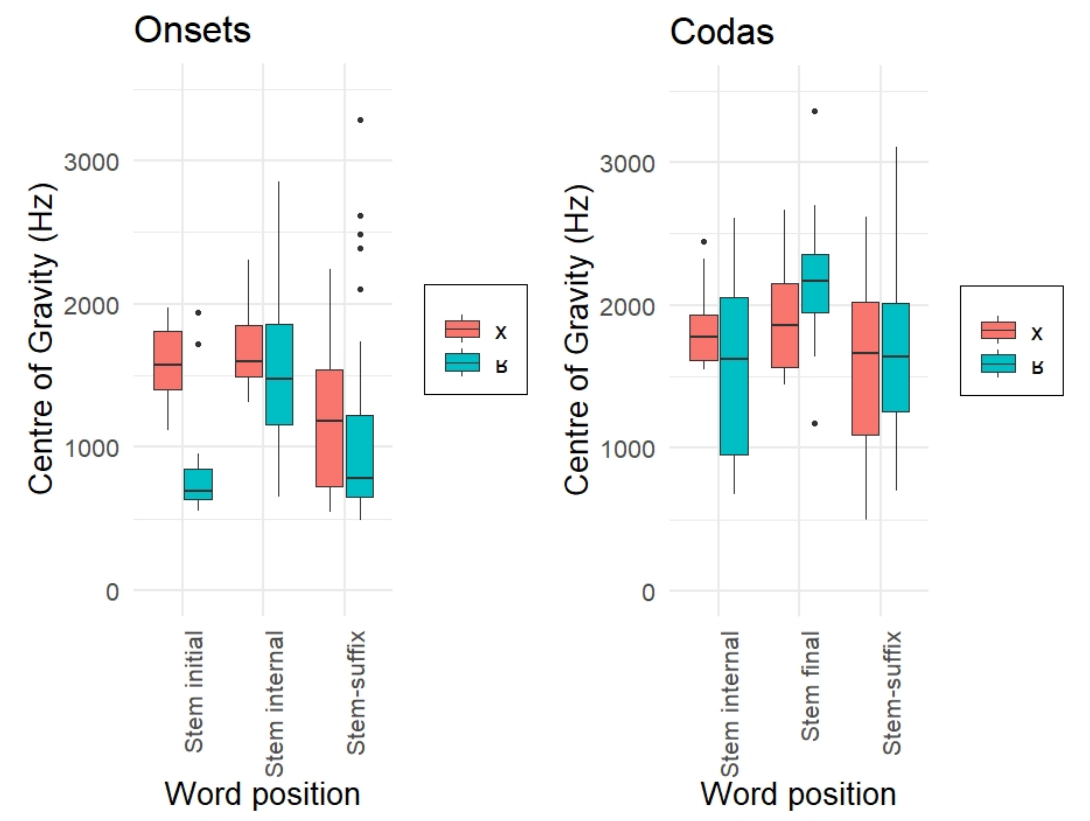

Figure 4. Centre of gravity of target coronal consonants $/ \mathrm{x} /$ and $/ \mathrm{B} /$

The above figures show some exceptions to the generalisations for the dorsals. First, steminternal values seem to follow the overall pattern whereby the voiceless fricative has higher cen- 
tre of gravity values than the voiced fricative, as well as the velar has higher centre of gravity values than uvulars. Second, the stem-final uvular fricative shows higher centre of gravity values word-finally. This differs with stem-final target voiceless fricative that show lower centre of gravity values at the stem-suffix boundary in onset position with a following vowel-initial suffix. Third, stem-final velar and uvular fricatives that show similar centre of gravity values at the stem-suffix boundary in coda position with a following consonant-initial suffix that show slightly lower values, yet still similar, when compared to stem-internal codas. These results are indications of word-final devoicing and intervocalic voicing with a following vowel-initial suffix but no voicing effects with a following consonant-initial suffix.

4.5. VOWEL DURATION. This section presents the results for vowel durations preceding coda $/ \mathrm{k} /$, /g/, /q/, / / /, and / / /. Preceding onset consonants do not seem to exhibit any influence on a following vowel (e.g., Peterson and Lehiste 1960) so I restrict myself to examining vowel duration of vowels preceding coda consonants. Vowel duration preceding stops and fricatives in coda position can be an indication for the voicing feature of the consonants (e.g., Chen 1970, Raphael 1972, Wade 2017). The expected pattern is shorter vowel durations preceding voiceless consonants and longer vowel durations preceding voiced consonants. In addition, shorter vowel durations preceding stops and longer vowel durations preceding fricatives.

The results show overall that vowels have shorter durations preceding voiceless consonants and have longer durations preceding voiced consonants, based on the median values. This can be shown in Figure 5.
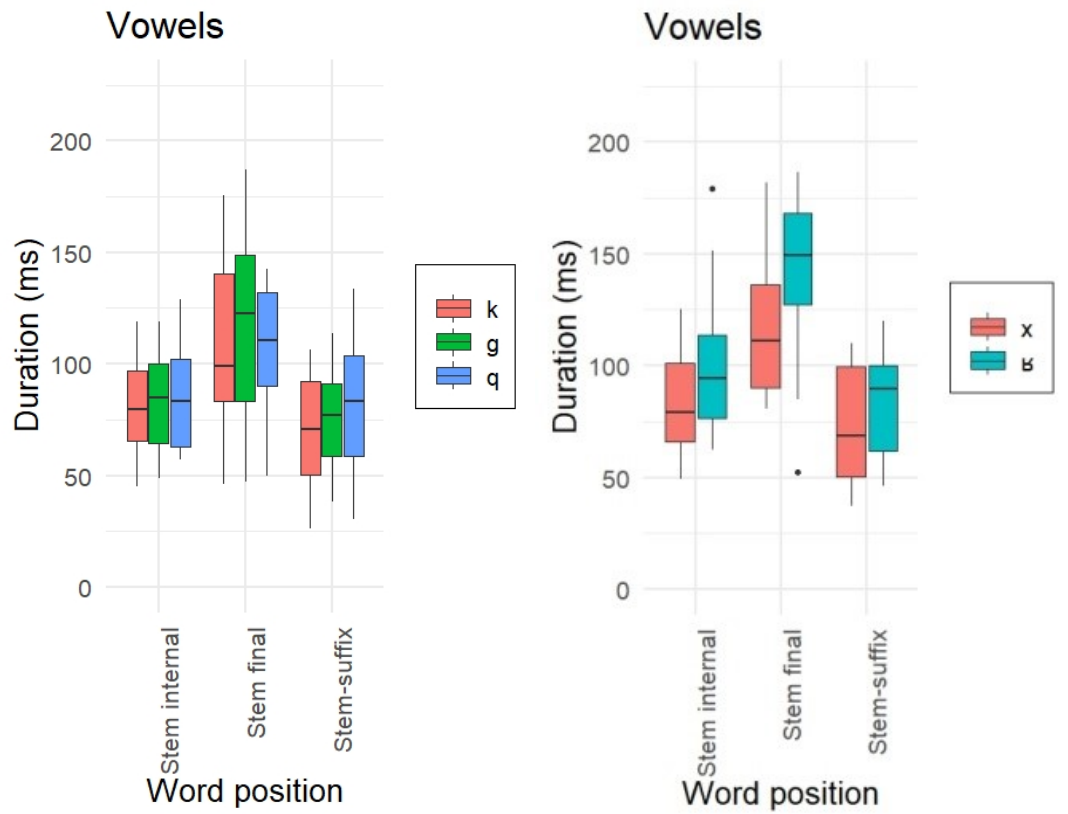

Figure 5. Vowel duration of target stop and fricative consonants /k/, /g/, /q/, /x/, and /s/

The target consonants clearly follow the generalisation whereby vowels have shorter durations preceding voiceless consonants than preceding voiced consonants. However, the stem boundary shows some unanticipated results. Vowels showed longer durations overall preceding stem-final consonants while still following the overall generalisation, Based on what we know about vowel durations preceding voiced and voiceless consonants, it was unexpected to not see shorter vowel 
durations preceding voiced consonants. Vowel durations preceding target voiced consonant did not have similar values with vowel durations preceding target voiceless consonants in the environment where word-final devoicing is expected, based on the stop and fricative results summarised in the previous sections above. Thus, these results indicate there is a lack evidence to show word-final devoicing. This could be in part due to the fact that the final syllable of a word in Kazakh is the position of word stress and so vowel duration will generally be longer.

4.6. F2 TRANSITION INTO/OUT OF CONSONANTS. This section presents the results for the transition of the vowels into and out of $/ \mathrm{k} /, / \mathrm{g} /, / \mathrm{q} /, / \mathrm{x} /$ and $/ \mathrm{s} /$. The $\mathrm{F} 2$ frequency, which determines the backness of the tongue body, shows to be the determining factor for distinguishing between velars and uvulars. The $10 \%$ onset of vowels adjacent to target onset velars and uvulars and the $90 \%$ offset of vowels adjacent to target coda velars and uvulars were measured. Kazakh allows different vowels to appear in initial syllables and non-initial syllables. The specific vowels used in the nonce words were $/ \mathrm{I} /, / \varnothing /, / \mathrm{e} /, / \mathrm{ur} /, / \mathrm{\sigma} /$, and $/ \mathrm{a} / .{ }^{10} / \mathrm{I} /$ and $/ \mathrm{a} /$ are unrestricted in what syllable they may appear (as are /e/ and / $/ \mathrm{u} /$ ) but $/ \varnothing /$ and $/ \mho /$ can only appear in initial syllables.

The results show overall that front vowels have higher F2 values and back vowels have lower F2 values. This can be shown in Figure 6, Figure 7, Figure 8, Figure 9, and Figure 10. ${ }^{11}$

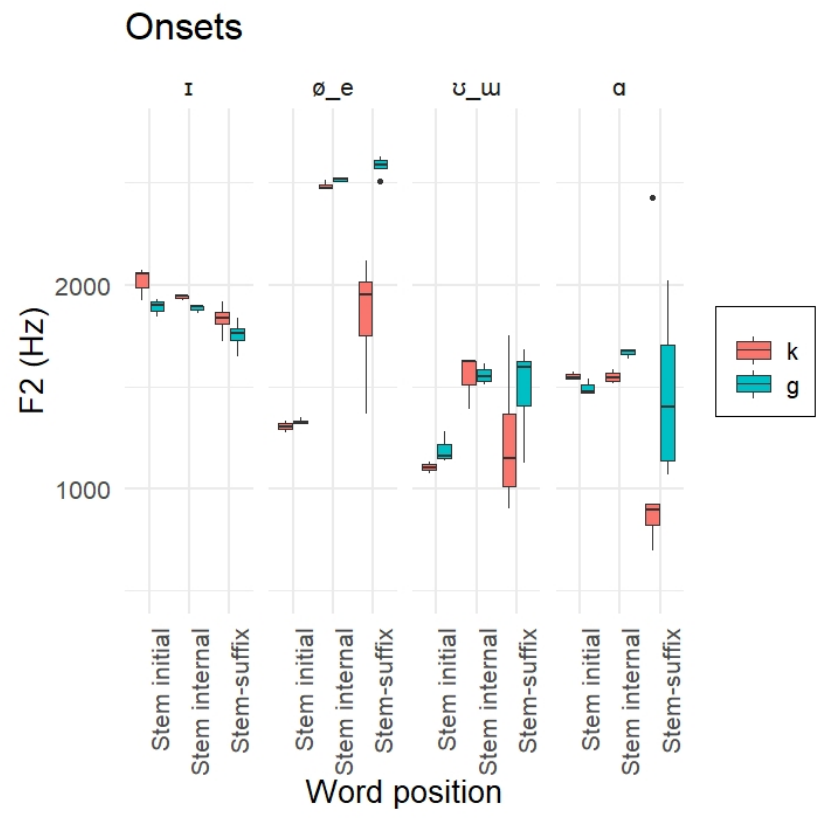

Figure 6 . F2 values at the $10 \%$ onset of vowels adjacent to velars

\footnotetext{
${ }^{10}$ Kazakh has eleven monothong vowels (Bowman \& Lokshin. 2013). Only six vowels were used in the nonce word create to reduce the number of nonce words altogether.

${ }^{11}$ In the figures, /ø/ and / / appear in the initial syllable position, while /e/ and /u/ appear in the non-initial syllable positions.
} 


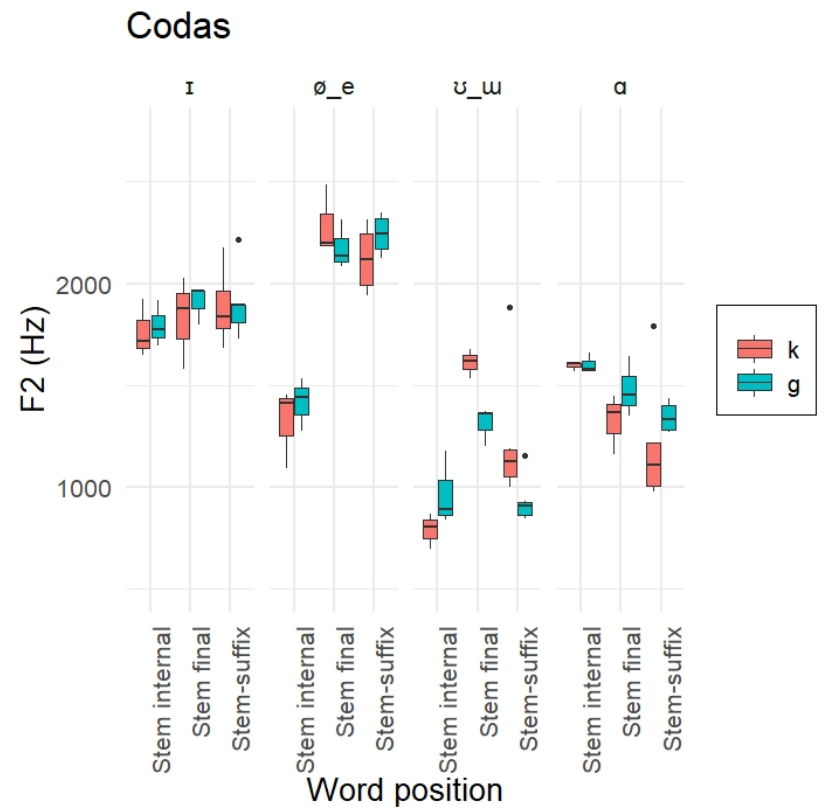

Figure 7. F2 values at the $90 \%$ offset of vowels adjacent to velars

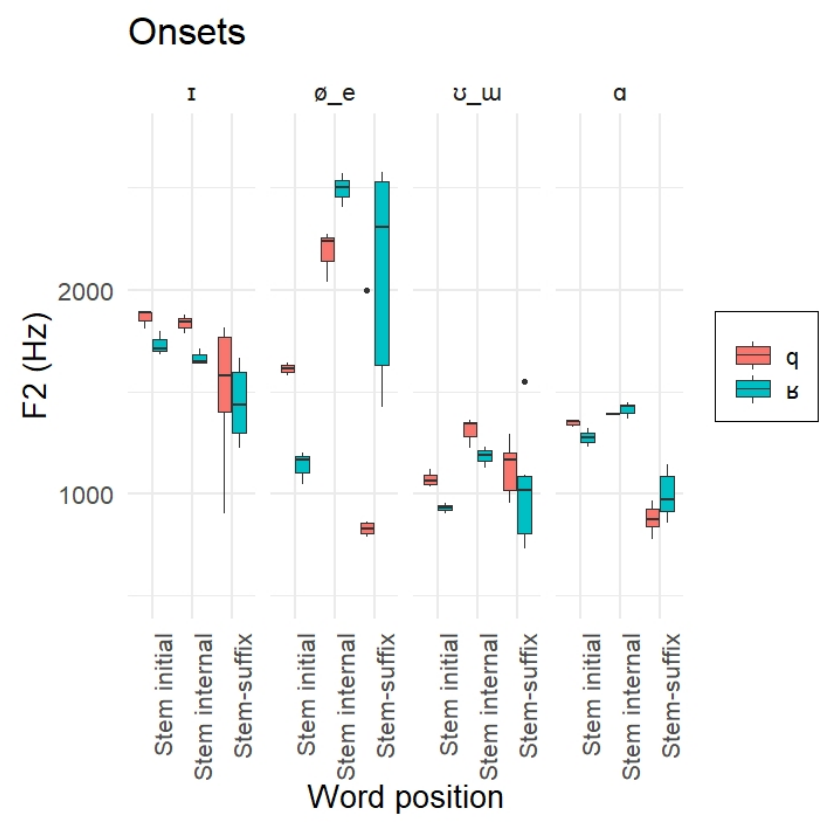

Figure 8 . F2 values at the $10 \%$ onset of vowels adjacent to uvulars 


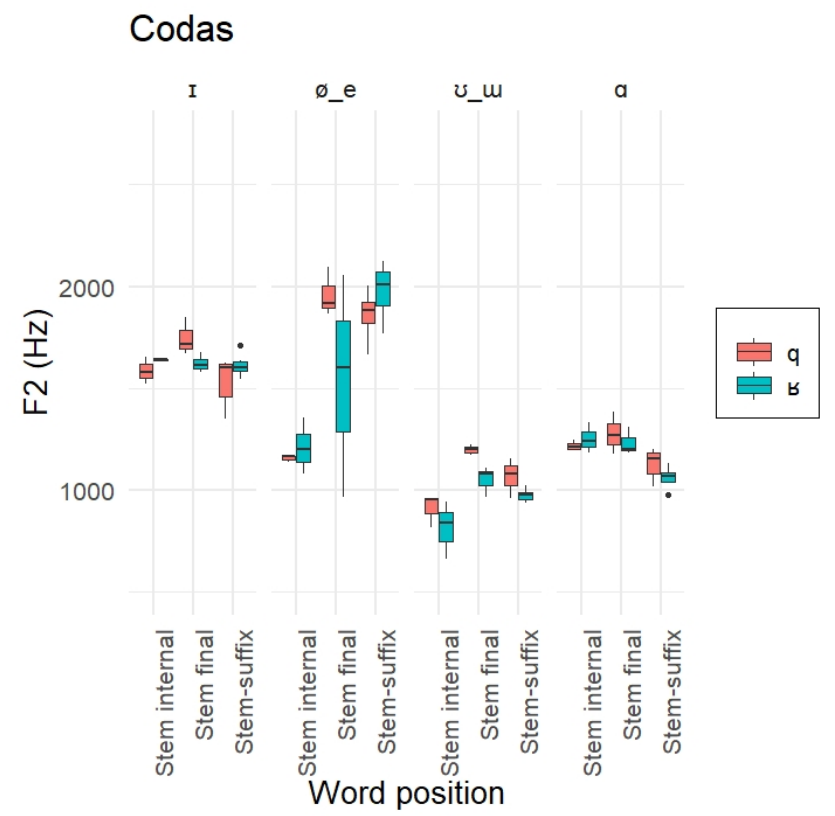

Figure 9. F2 values at the $90 \%$ offset of vowels adjacent to uvulars
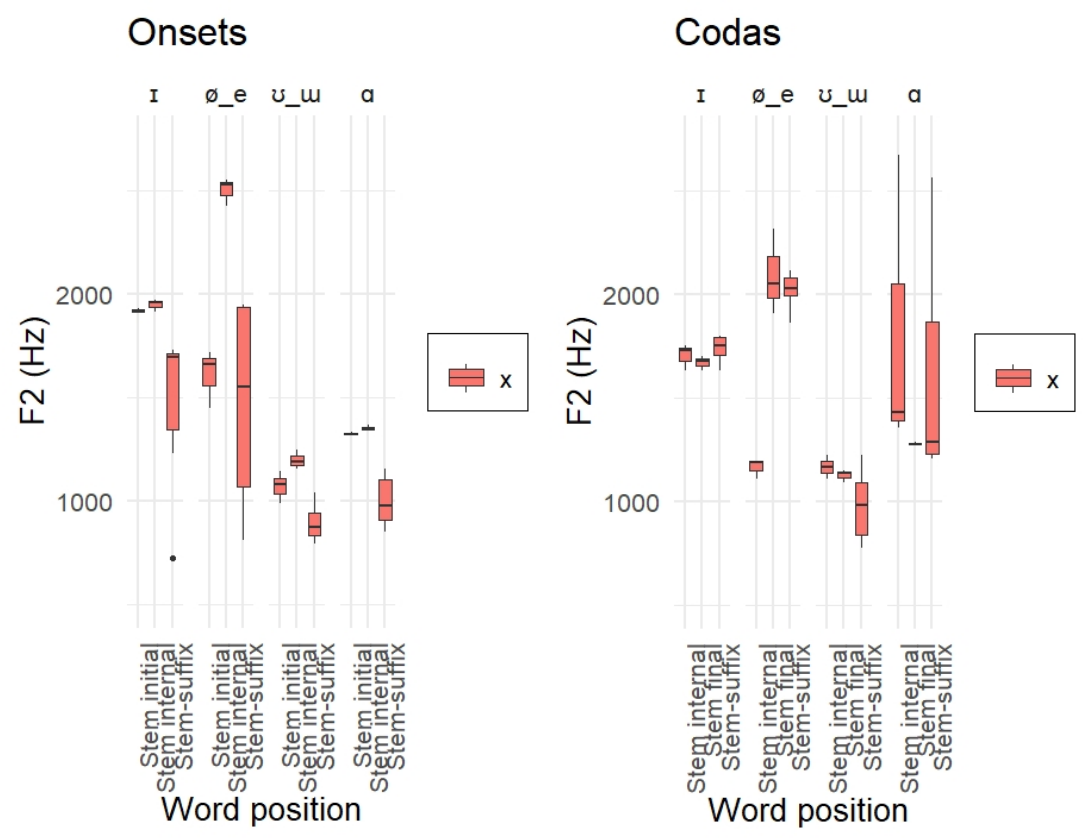

Figure 10 . F2 values at the $10 \%$ onset and $90 \%$ offset of vowels adjacent to /x/

Front vowels have higher F2 values adjacent to velars than uvulars and back vowels have lower F2 values adjacent to uvulars than velars. However, the above figures show some exceptions. First, /e/ adjacent to onset consonants at the stem-suffix boundary shows a greater range of F2 values relative to the other vowels. Additionally, /a/ adjacent to word-internal coda consonants (whether it be stem-internal or at the stem-suffix boundary) also shows a greater range of F2 values. It is also unsurprising the range of values for dorsal consonants when considering that front vowels adjacent to uvular consonants and back vowels adjacent to velar consonants since these are unnatural combinations for native Kazakh words. The unexpected observation comes 
from $/ x /$, whereby the speaker assimilated its place of articulation based on the adjacent vowel. Thus, $/ \mathrm{x} /$ seems to pattern with velars adjacent to front vowels and with uvulars adjacent to back vowels. These results are indications that the F2 transitions into and out of velars and uvulars show different places of articulation and $/ \mathrm{x} /$ undergoes place assimilation depending on whether it is adjacent to front or back vowels.

5. Discussion. The production of nonce words by the native Kazakh speaker reveals that the place restriction was not productive (\$5.1) but the voicing restriction was productive (§5.2). Even with very few tokens and one speaker, the voicing restriction ultimately contributes the most to the description of Kazakh.

5.1. Place of articulation ReStRiction. The acoustic properties confirm the place restriction is not productive. The restriction that is observed in real words was not extended to nonce words. I expected the speaker to produce velar consonants in front vowel environments and uvular consonants in back vowel environments when reading from written stimulu. I also expected the segment's voicing designation to not be an issue since voiced and voiceless dorsals can occur word medially within a root. The speaker invariably was able to produce the target velars and uvulars regardless of whether the adjacent vowels were front or back. The voiceless fricative $/ \mathrm{x} /$ showed a sign of place of articulation assimilation but this segment was produced as a voiceless fricative with no indication of varying freely with the voiceless uvular stop [q].

There are a few explanations for this. First, it is possible that the place restriction is no longer productive. The pattern whereby velars appear in front vowel environments and uvulars appear in back vowel environments would not be extended to new words. Second, it is possible that the speaker treated the nonce words as loanwords and so they would produce velars and uvulars faithfully, instead of adjusting their pronunciation, since the place of articulation restriction is not found in loanwords. In many languages, loanwords are often exceptional crosslinguistically and may allow less restrictive phonotactic requirements than for native words (see Kang 2011 for an overview). Third, neutralisation is no longer complete and this could be due to the task effect. This could stem from the effects of reading tasks using written stimuli and the influence that orthography can have on oral speech. If spelling suggests a difference, a speaker may make the distinction when speaking carefully (e.g., Roettget et al. 2014).

5.2. VOICING RESTRICTION. The acoustic properties confirm the voicing restriction is productive. The restriction that is observed in real words was extended to nonce words. I expected the speaker neutralise voiced velar $/ \mathrm{g} /$ to voiceless $[\mathrm{k}]$ and voiced uvular $/ \mathrm{b} /$ to voiceless [q]. I also expected the speaker to voice stem-final target velar and uvular consonants intervocalically with a following vowel-initial suffix. The speaker produced voiceless velars and uvulars word-finally and voiced velars and uvulars intervocalically with a following vowel-initial suffix. However, there were unexpected results. First, word-final $/ \mathrm{g} / \mathrm{devoiced}$ to $[\mathrm{k}]$ but the word-final $/ \mathrm{s} / \mathrm{did}$ not neutralise to [q], but devoiced to $[\chi]$ instead when reading from written stimuli. Thus, the manner of articulation was maintained. Second, the speaker respected the voicing restriction by voicing stem-final $/ \mathrm{k} /$ and $/ \mathrm{q} /$ to $[\mathrm{g}]$ and $[\mathrm{b}]$, respectively, intervocalically with a following vowel-initial suffix. Third, the stem-final $/ \mathrm{x} /$ showed intervocalic voicing effects when followed by a vowelinitial suffix, matching real word production.

There are a few explanations for this. First, as seen above regarding the place of articulation restriction, it is possible that the speaker treated nonce words as loanwords, even though she was 
asked to treat them as if they were real words. This can be seen from word-final $/ \mathrm{b} /$ invariably devoicing to $/ \chi /$. This phenomenon can be modelled using a co-phonology approach (e.g., Inkelas $\&$ Zoll 2007) or indexed constraints (e.g., Flack 2007). The co-phonology approach captures diversity between native and loanword phonology by associating a lexical or morphological class with a different phonological grammar, while the indexed constraint approach captures diversity under a single constraint ranking for an entire language but a constraint within the ranking is indexed to an individual morpheme. Second, it is possible that neutralisation is incomplete. As seen above regarding the place of articulation restriction a reading task using written stimuli can show the influence orthography has on oral speech. This was demonstrated by the speaker producing $[\chi]$, instead of [q], word-finally, as well as her ability to produce velars adjacent to a back vowel and uvulars adjacent to a front vowel. Third, the morphological boundary constitutes a specific environment for voicing to occur, as opposed to the identical environment found wordinternally. The following examples shown in (6) are the speaker's production of target velars and uvulars in a small sample of nonce words.

(6) Intervocalic velar and uvular consonants within a word and at a morpheme

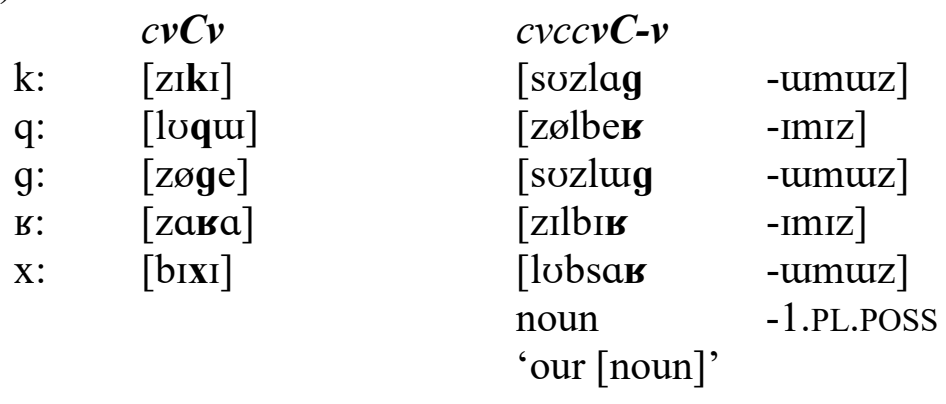

The local domain of the suffix can be characterised as a derived-environment effect since the voicing alternation is limited to the morpheme boundary and so the phonological process is conditioned morphologically (Burzio 2011).

6. Conclusion. This paper looked at the Kazakh velars and uvulars, in terms of the place of articulation and voicing phenomena. Existing descriptions contain limited amounts of data and so it is difficult to make any generalisation regarding the full distribution of velars and uvulars.

I conducted two elicitation-based production experiments using nonce words with a native Kazakh speaker to answer my research questions. Different acoustic properties, including closure duration, voice onset time, frication duration, centre of gravity, vowel duration and F2 values, were examined to determine whether the speaker varied in their production of target velars and uvulars that could distinguish place of articulation and voicing. The acoustic properties confirmed that the place of articulation restriction was not productive, but the voicing restriction was productive.

\section{References}

Akpanglo-Nartey, Jonas N. 1982. On fricative phones and phonemes: Measuring the phonetic differences within and between languages. UCLA working papers in phonetics, 55, pp. 1-181. Batayeva, Zaure. 2013. Colloquial Kazakh: the complete course for beginners. New York: Routledge.

Bekturova, A. and Sh. Bekturov. 1996. Manual of the Kazakh language. Almaty: Rauan. 
Boersma, Paul. 2001. Praat, a system for doing phonetics by computer. Glot International 5 (9/10): 341-345.

Bowman, Samuel. R. and Benjamin Lokshin. 2013. Idiosyncratically transparent vowels in Kazakh. In Proceedings of Phonology, ed. John Kingston, Claire Moore-Cantwell, Joe Pater and Robert Staubs. Oxford: Oxford University Press.

Burzio, Luigi. 2011. Derived environment effects. In Blackwell Companion to Phonology, ed. Marc. van Oostendorp, Colin J. Ewens, Elizabeth Hume and Keren D. Rice. 2089-2114. Meldon, MA: Blackwell Publishing.

Chen, Matthew. 1970. Vowel length variation as a function of the voicing of the consonant environment. Phonetica 22: 129-159.

Cho, Taehond \& Peter Ladefoged. 1999. Variations and universals in VOT: evidence from 18 endangered languages. Journal of Phonetics 27, 207-229.

Flack, Kathryn. 2007. Templatic morphology and indexed markedness constraints. Linguistic Inquiry 38: 737-748.

Gordon, Matthew, Paul Barthmaier and Kathy Sands. 2002. A cross-linguistic acoustic study of voiceless fricatives. Journal of the International Phonetic Association 32, 141-174.

Gradoville, Michael Stephen. 2011. Validity in measurements of fricative voicing: Evidence from Argentine Spanish. Proceedings of the $5^{\text {th }}$ Conference on Laboratory Approaches to Romance Phonology: 59-74.

Inkelas, Sharon and Cheryl Zoll. 2007. Is grammar dependence real? A comparison between cophonological and indexed constrain approaches to morphologically conditioned phonology. Linguistics 45: 133-172.

Itô, Junko and Armin Mester. 2001. Covert generalization in Optimality Theory: The role of stratal faithfulness constraints. Studies in Phonetics, Phonology, and Morphology 7: 273-299.

Johanson, Lars and Eva Agnes Csato Johanson. 1998. The Turkic Languages. New York, NY: Routledge

Kang, Yoonjung. 2011. Loanword Phonology. In Blackwell Companion to Phonology, ed. Marc. van Oostendorp, Colin J. Ewens, Elizabeth Hume and Keren D. Rice. 2258-2282. Meldon, MA: Blackwell Publishing.

Kara, DávidSomfai. 2002. Kazak. Muenchen: Lincom Europe.

Klatt, D. H. 1976. Linguistic uses of segmental duration in English: Acoustic and perceptual evidence. Journal of the Acoustical Society of America 59: 1208-1221.

Lehiste, Ilse. 1970. Suprasegmentals. Cambridge, MA: MIT Press.

Maddieson, Ian. 1997. In The Handbook of Phonetic Sciences, ed. William J. Hardcastle and John Laver. Oxford: Blackwell Publishing, 619-639.

Manrique, Ann María and María Ignacia Massone. 1981. The role of formant transitions in the identification of Spanish fricatives. Journal of the Acoustical Society of America 69: 11451153.

Muhamedowa, Raihan. 2016. Kazakh: A Comprehensive Grammar. New York, NY: Routledge.

Peterson, Gordon E, and Ilse Lehiste. 1960. Duration of syllable nuclei in English. Journal of the Acoustical Society of America, 32(6), 693-703.

Raphael, Lawrence J. 1972. Preceding vowel duration as a cue to the perception of the voicing characteristic of word-final consonants in American English. The Journal of the Acoustical Society of America 51 (4): 1296-1303.

Roettget, T.B., B. Winter, S. Grawunder, J. Kirby, and M. Grice. 2014. Assessing incomplete neutralization of final devoicing in German. Journal of Phonetics 43: 11-25. 